\title{
Candidate gene loci in asthmatic and allergic inflammation
}

Medical genetics was revolutionised during the 1980 s by the application of genetic mapping to locate the genes responsible for simple Mendelian diseases. Most diseases, however, do not follow simple inheritance patterns, and geneticists have now taken up the even greater challenge of the genetic dissection of complex diseases such as hypertension, ischaemic heart disease, and asthma. This editorial sets out to review recent work which has attempted to determine the genetic basis of atopy and asthma with a focus on immunopharmacological mechanisms. The review excludes recent reports of $\beta$ adrenoceptor polymorphisms, asthma severity, and bronchodilator responsiveness, nor do we discuss the genetics of chronic obstructive pulmonary disease (COPD) which have recently been reviewed elsewhere. ${ }^{12}$

One of the first problems encountered in this endeavour is definition of the phenotype. Asthma is a clinical diagnosis with no foolproof diagnostic test, so surrogate markers for the disease are used including atopy, bronchial hyperresponsiveness, and clinical history. Inevitably this leads to disagreement between various research groups and an inability to compare results achieved using different definitions. Genetic heterogeneity, incomplete penetrance, and environmental factors may also confound statistical analysis and make it difficult to reproduce positive findings.

Strategies for determining the genetic basis for asthma and allergy include using random markers to screen the entire genome looking for evidence of linkage to the disease or disease associated traits; this approach is now feasible given the increasing number of DNA polymorphisms available for such a purpose and has been used successfully by Todd's group in Oxford in their search of the human genome for genes that predispose to type 1 insulin dependent diabetes mellitus. ${ }^{3}$ Another approach would be to examine markers in and around candidate loci whose products are thought to be important in the pathogenesis of the disease; examples of this include the $\mathrm{IgE}$ receptor on chromosome 11, the cytokine cluster on chromosome 5 , and the $\mathrm{T}$ cell receptors on chromosomes 7 and 14 . Both these approaches have been used in recent studies on the genetics of asthma and atopy.

\section{IgE, atopy and asthma}

Problems with definition of the asthma phenotype have led researchers to study atopy, a major risk factor for the development of asthma, as characterised by a persistent IgE-mediated response to common environmental allergens. Atopy, which contributes to diseases such as asthma, eczema, and allergic rhinitis, is defined as a disorder of the $\mathrm{IgE}$ response to common allergens such as pollen, animal dander, house dust mites, and fungi. ${ }^{4}$ These diseases are frequently detected by a raised total serum IgE level, a raised specific IgE level, and positive skin tests to common aeroallergens.

Burrows et $a l^{5}$ investigated the association of self-reported asthma or allergic rhinitis with serum IgE levels and skin test reactivity to allergens in 2657 subjects in a general population study. Regardless of the atopic status of the subjects or their age group, the prevalence of asthma was closely related to the serum total IgE level standardised for age and sex. No asthma was present in the 177 subjects with the lowest IgE levels for their age and sex. The conclusion reached was that asthma is almost always associated with some type of IgE-related reaction and therefore has an allergic basis. Further evidence for the relationship between IgE levels and asthma has been provided by Sears et al who studied the relationship between serum total IgE levels and airway responsiveness to methacholine challenge in the presence or absence of asthma in a birth cohort of New Zealand children. ${ }^{6}$ The prevalence of diagnosed asthma was significantly related to the serum IgE level, and airway hyperresponsiveness was still related to an allergic diathesis as reflected by the serum total IgE level even in children who had been asymptomatic throughout their lives and had no history of atopic disease.

Bronchial hyperresponsiveness, atopy and asthma Further work by Sears et al on the same cohort of children has looked at the relationship between airway hyperresponsiveness, asthma and atopy. ${ }^{7}$ Airway hyperresponsiveness (methacholine $\mathrm{PC}_{20} \mathrm{FEV}_{1}<8 \mathrm{mg} / \mathrm{ml}$ ) was found to be strongly correlated with reported asthma and wheezing and with atopy as defined by positive skin prick test, particularly to house dust mite and cat. Furthermore, all the children with diagnosed asthma and airway hyperresponsiveness were atopic. They concluded that atopy was a major determinant of airway hyperresponsiveness in children, not only in those with a reported history of asthma and wheezing, but also in those without any history suggestive of asthma and rhinitis.

There is clearly a link between atopy, airway hyperresponsiveness, and asthma, although the precise relationship remains a source of considerable debate. There is a tendency to dichotomise subjects as hyperresponsive or non-responsive on the basis of whether or not their forced expiratory volume in one second $\left(\mathrm{FEV}_{1}\right)$ falls by $20 \%$ at a given dose of inhaled histamine or methacholine, and different cut off doses have been used by different workers. On the basis of this, one would hope to be able to discriminate clearly between asthmatics and nonasthmatics. However, some atopic subjects with no evidence of symptomatic asthma will also demonstrate bronchial hyperresponsiveness according to the same criteria, as will a small percentage of normal subjects. ${ }^{8}$ Enhanced bronchial responsiveness has a strong association with clinically defined asthma, and the association appears to be stronger in those with more immediate and severe symptoms and with greater treatment requirements, although the overlap between groups is large. ${ }^{9}$ Moreover, there is documentation from longitudinal studies that bronchial hyperresponsiveness may not be present in some people at a time when they have unmistakable asthma symptoms and airway obstruction and, conversely, that greatly enhanced bronchial responsiveness may be present in the absence of symptoms, or may develop after symptoms have become manifest as occurs in seasonal asthma. ${ }^{1011}$ Thus, although bronchial hyperresponsiveness and asthma are related, the two are not synonymous.

A number of variables have been shown to affect both serum IgE levels and bronchial hyperresponsiveness. Smoking, for example, has been shown to lead to an increase in total serum IgE levels. ${ }^{12}$ The effects of age on 
serum IgE levels are not clear, with studies showing variably a decline, no change, or an increase. ${ }^{13}$ Environmental factors undoubtedly influence basal levels of $\operatorname{IgE}$ and will vary depending on the age of the subject and on the time of year the sample was taken. Ideally, therefore, multiple samples should be taken and looked at for seasonal variation. The prevalence of atopy has been shown to be higher in boys than girls, ${ }^{14}$ although mean IgE levels do not differ significantly between the sexes. ${ }^{6}$ Bronchial hyperreactivity may also be affected by smoking and previous history of respiratory illness. ${ }^{1516}$ These variables should be taken into account in any analysis which uses IgE or bronchial hyperresponsiveness as surrogate markers of atopy or asthma.

\section{Genetics of IgE}

The familial incidence of atopic disease is high; most family studies report a positive family history in approximately $50 \%$ of cases. However, the mode of inheritance is disputed, and a single dominant gene with partial penetrance, a single recessive gene with partial penetrance, and multigene inheritance have all been suggested. Studies looking at $\operatorname{IgE}$ levels in twins have found that monozygotic twins are substantially more similar to each other than are otherwise comparable dizygotic twins of a pair. ${ }^{17-20}$

There are several theories as to the mode of inheritance of IgE. Gerrard et al studied IgE levels in parents and children. ${ }^{21}$ The results from an analysis of 80 families were consistent with low levels of IgE being determined by two dominant genes, the absence of one or the other permitting high levels to occur. Further data acquired from 173 nuclear families supported the hypothesis of a regulatory locus for IgE occupied by two alleles with the dominant allele suppressing persistently high levels of IgE. Their data were subsequently reanalysed and the findings not confirmed. ${ }^{22}$ A further study of IgE distribution in three large pedigrees suggested a strong hereditary involvement with high levels being determined by a dominant allele. ${ }^{23}$ A study of $\operatorname{IgE}$ levels in five pedigrees selected through breast cancer probands provided evidence for the presence of a polygenic component in the determination of $\operatorname{IgE}$ with no evidence of a major gene effect. ${ }^{24}$ Meyers et al attempted to resolve the confusion over the genetic basis of $\operatorname{IgE}$ production by studying 42 families ( 278 individuals) deliberately not selected for the presence of atopy. Segregation analysis showed that the mixed model of recessive inheritance of high levels was most appropriate for their data, with approximately $36 \%$ of the total phenotypic variation in $\log$ (IgE) attributable to genetic factors equally divided between Mendelian and more general polygenic components. ${ }^{25}$

It is apparent from the plethora of studies addressing this issue and reaching different conclusions that the study of the genetics of IgE production is fraught with difficulties. Ascertainment of the sample population to be analysed may introduce a substantial source of potential bias into any results. A study published by Cookson et $a l^{26}$ found evidence for vertical transmission of atopy as defined by a positive skin prick test ( $>1 \mathrm{~mm}$ than the negative control), a serum total IgE level $>2.5$ standard deviations above the mean for the normal population, and one or more positive RAST tests to a panel of allergens. Only one of the above criteria had to be met for the patient to be designated atopic. It was concluded from an analysis of the data that atopy is inherited as an autosomal dominant trait. The study was based on a sample of 20 nuclear families recruited via asthmatic probands from outpatients at a chest clinic with a control group recruited from patients admitted to hospital for other reasons. In addition, three large families with asthmatic members were recruited - two by means of letters to general practitioners and one in response to an article in the local newspaper. It was felt that the inheritance pattern of atopy with particular regard to the extended families clearly indicated autosomal dominant transmission. With such a broad definition of atopy and the inclusion of extended pedigrees with such a strong history of atopy, it is difficult to reject an autosomal dominant model, but this does not necessarily imply that it is correct. Furthermore, when the same group undertook segregation analysis on an Australian cohort of 234 random families "adjusting" total IgE for atopy, they reported a major recessive gene which does not seem consistent with the previously held view of atopy as an autosomal dominant trait. $^{27}$

\section{Chromosome $11 q$}

In 1989 the Oxford group presented evidence for a single major autosomal dominant "atopy gene" linked to the D11S97 marker on chromosome 11q13 with strong evidence for linkage (lod score $=5.58$ ) at a recombination fraction of $0 \cdot 1$. Most of the lod score (3.14) was contributed by a single family having 23 meioses. ${ }^{28} \mathrm{~A}$ second study to confirm this finding was undertaken on a sample of 64 nuclear families recruited from asthma and allergy clinics and by appeal in the media. Linkage analysis to D11S97 this time provided a lod score of 3.80 at a recombination fraction of $0 \cdot 07 .{ }^{29}$ Pooling of these two samples gave a lod score of 9.33 at a recombination fraction of 0.92 . In a summary paper, a lod score of 10 was reported on a sample of "over 800 individuals from over 50 nuclear and 20 extended British families". ${ }^{30}$ This agrees substantially with the sum of their two published samples. Shortly afterwards a lod score of 3.88 was reported with a recombination fraction of $0 \cdot 25 .{ }^{31}$ No explanation has been advanced for the loss of more than $60 \%$ of the information between the studies.

Support for linkage data to chromosome 11q comes from a study published by Shirakawa et al on four families with 69 meioses selected from 270 families using an extreme definition of atopy, and a report by Collee et al in a small sample of affected sibling pairs. ${ }^{3233}$

Following on from initial linkage studies, the Oxford group showed that the $\beta$ unit of the high affinity receptor for IgE $\left(\mathrm{FC}_{\varepsilon} \mathrm{R} 1 \beta\right)$ was also located on chromosome $11 \mathrm{q} 13$ and was in close linkage with the gene for atopy. ${ }^{34}$ IgEmediated mast cell or basophil activation occurs through the interaction of multivalent antigen with antigen-specific IgE bound to high affinity IgE receptors $\left(\mathrm{Fc}_{\varepsilon} \mathrm{R} 1\right){ }^{35}$ The $\mathrm{Fc}_{\varepsilon} \mathrm{R} 1$ receptor consists of one alpha chain, one beta chain, and two gamma chain subunits (fig 1). ${ }^{36}$ The $\alpha$ chain contains one membrane-spanning region and the single IgE binding site. The $\beta$ chain has four membrane-spanning domains with both the amino and carboxy terminals protruding into the cell cytoplasm. The two $\gamma$ chains have a single membrane-spanning region. The $\beta$ subunit is involved in the critical process of tyrosine phosphorylation of cross-linked $\mathrm{Fc}_{\varepsilon} \mathrm{R} 1$ subunits leading to the assembly of a "signalling complex" of receptor associated proteins. This, in turn, leads to the production of inositol phospholipids which cause a rise in intracellular calcium essential for the release of vasoactive mediators from inflammatory cells. ${ }^{37}$ Stimulation of the receptor on mast cells and basophils also provokes the release of interleukin 4 which, through a cognate interaction with CD40 and its ligand on B cells, may lead to isotype B cell switching to IgE synthesis. ${ }^{38} 39$

Shirakawa et al performed DNA sequence analysis on six atopic and six non-atopic individuals and revealed one 


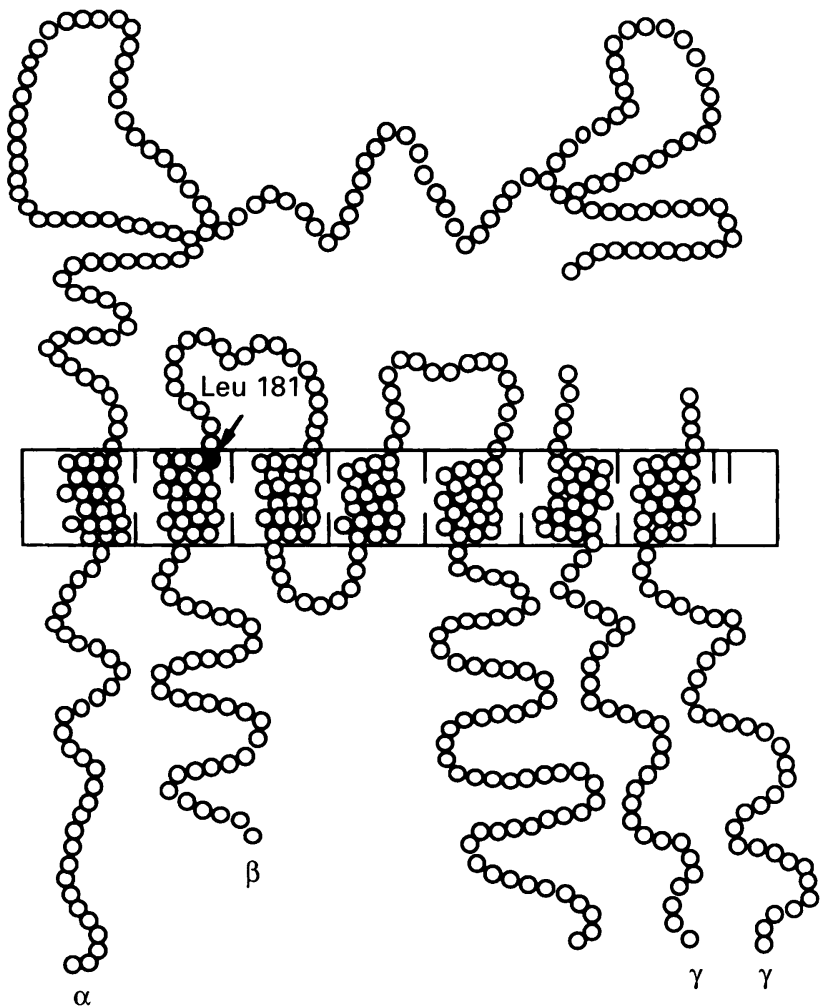

Figure 1 Schematic representation of $F_{c_{i}} R 1$ showing the Leu 181 substitution in the fourth transmembrane domain of the $\beta$ subunit.

patient with a variant sequence in which a leucine was substituted for an isoleucine at position 181 in the fourth transmembrane domain of the $\beta$ subunit (fig 1). ${ }^{40}$ The presence of this variant and its association with atopy was examined in a random sample of patients unselected for atopy and 60 families ascertained through a young asthmatic proband with at least one other sibling and both parents available for study. Associations were reported between the presence of Leu 181 and high total serum IgE levels. From the 60 nuclear families with allergic asthmatic probands, Leu 181 was identified in $10(17 \%)$, was maternally inherited in each, and was reported to show a strong association with atopy. While reporting linkage to $11 \mathrm{q}$, Collee et al failed to reveal evidence of significant linkage to the $\mathrm{FC}_{\varepsilon} \mathrm{Rl}$ locus implying that other genes on this chromosome may be involved. ${ }^{33}$

These potentially exciting findings were consistent with a further observation that the transmission of atopy at the $11 \mathrm{q}$ locus was only detectable through the maternal line. ${ }^{41}$ It was argued that this was consistent with paternal imprinting or with maternal modification of the developing immune response. Their data showed that $125(62 \%)$ of sibling pairs affected by atopy shared the maternal $11 \mathrm{q} 13$ allele and $78(38 \%)$ did not. This distribution differs significantly from the expected $50 / 50$ distribution $(\mathrm{p}=$ 0.001 ), suggesting an excess sharing of maternal alleles in affected siblings.

Intrauterine environmental factors may in part account for the maternal influence over the immune response of the progeny in favour of atopy. Work from the MRC Environmental Epidemiology at Southampton has provided interesting data concerning possible maternal effects on the developing immune response of the fetus. ${ }^{42}$ It has been shown that a raised serum IgE concentration in adult men and women was strongly correlated with a large head circumference at birth. This association was independent of adult size, social class, smoking, or gestational age at birth. One hypothesis that might explain this phenomenon is that disproportionate fetal growth resulting in a larger head circumference at birth may be associated with impaired thymic development with a diminished production of Th1 cells which are more sensitive to adverse environmental stimuli. ${ }^{43}$ Th 1 cells produce interferon $\gamma$, low levels of which at birth are thought to be a risk factor for the development of atopy. ${ }^{445}$

Although several groups have failed to replicate the findings of the Oxford group, ${ }^{46-50}$ all the studies cited have used different definitions and protocols, and on the whole sample sizes were small. We have also attempted to replicate the Oxford data on a large sample of 131 families recruited at random from general practitioner registers in Wessex. The families were selected solely for having three or more children, and all were typed for three markers on chromosome 11q. Using combined segregation and linkage analysis, no evidence was found for linkage to atopy, and mother-child and father-child correlations were virtually identical, making it difficult to substantiate imprinting of either parent. ${ }^{51}$ Neither is the theory of paternal imprinting supported by expression studies of imprinting from the homologous region of the mouse genome. ${ }^{52}$ To substantiate the findings reported by the Oxford group on chromosome $11 \mathrm{q}$, further studies are needed in populations enriched for asthma.

\section{Chromosome 14}

Atopic individuals differ in the allergens to which they react. The difference is clinically important, since asthma and bronchial hyperresponsiveness may be associated with allergy to house dust mite antigen but not necessarily to grass pollen. ${ }^{53}$ Genetic regulation of specific IgE responses is probably different from that of the general atopic response. Specific IgE reactions might be constrained by variation in the HLA or T cell receptor (TCR) proteins, since these molecules are central to the handling and recognition of foreign antigens. ${ }^{54}$ The role of the TCR in allergic reactions is unclear. The receptors consist of $\alpha$ and $\beta$ chains; the former arises from chromosome 14 and the latter from chromosome 7. Genetic linkage has recently been shown between specific IgE reactions to highly purified major allergens and the TCR- $\alpha$ complex on chromosome $14 . .^{55}$ Antigens tested included highly purified proteins from the house dust mite, Dermatophagoides pterynissinus, the domestic cat and dog, grass pollen, and the mould Alternaria alternata. Two independent sets of families, one British and one Australian, were studied. No linkage of IgE serotypes to TCR- $\beta$ microsatellite alleles was found, but significant linkage to TCR- $\alpha$ microsatellite alleles was seen in British sibling pairs with $\operatorname{IgE}$ responses to the house dust mite $(p=0 \cdot 0001)$. In Australian subjects there was excess sharing of alleles in siblings responsive to grass pollen $(p<0.005)$. It has been concluded that a gene in the TCR- $\alpha$ region modifies the specific IgE response.

\section{Chromosome 5}

There have been many studies looking at the relationship of HLA D encoded MHC class 2 genes and specific IgE responses suggesting linkage of certain haplotypes with individual responses to purified allergens. ${ }^{5456}$ This is referred to as the cognate, antigen specific arm of the IgE response. From Mossman's initial studies in mice, ${ }^{57} \mathrm{~T}$ helper lymphocytes in humans designated Th1-like and Th2-like play a crucial role in facilitating the immune response. Atopic subjects preferentially expand $\mathrm{T}$ cell clones with a "Th2" phenotype. The antigen-cognate interaction of Th2 cells with B cells involves the CD40- 
A
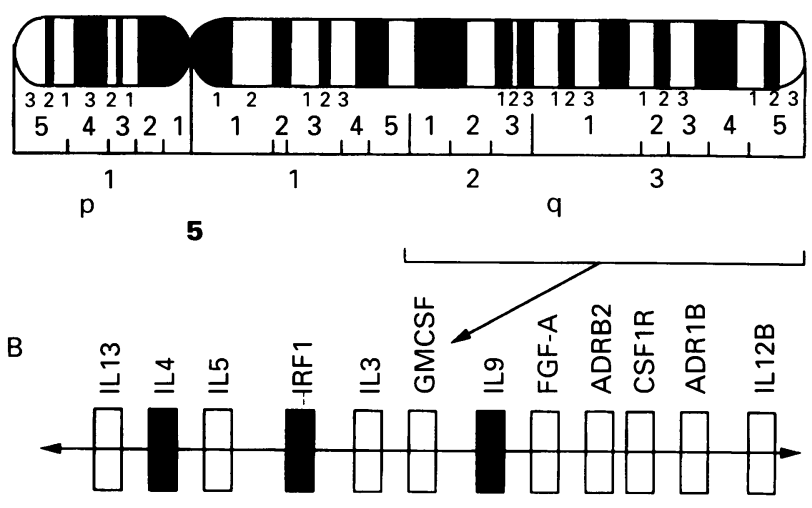

centromere

telomere

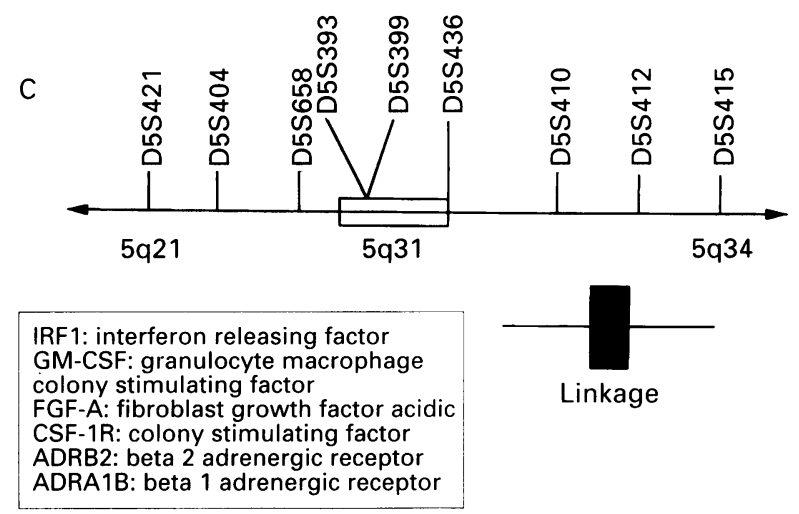

Figure 2 (A) Schematic representation of the banding pattern on chromosome 5. (B) Simplified genetic map of 5q21-q34 showing IL-4 cytokine gene cluster. (C) Map of genetic markers on chromosome 5.

CD40L binding, $\mathrm{B}$ cell activation, and the release of IL-4 and IL-13 from the Th2 cells. This process leads to Ig heavy chain class switching to the $\varepsilon$ isotype, resulting in specific IgE antibody responses. ${ }^{39} 58$ Interleukin 4 is crucial for the development and functioning of Th2 cells, including their ability to express IL-5, the cytokine largely responsible for eosinophilia in allergic disorders. It has also been shown that basophils and mast cells both produce IL-4. ${ }^{5960}$ The interaction of basophils and mast cells with $\mathrm{B}$ cells via the CD40-CD40L also leads to the production of IgE. ${ }^{38}$ This interaction is not antigen driven and is therefore said to be non-cognate. The IL- 4 gene has emerged as a major candidate for IgE responsiveness and atopy, with other candidate genes for atopic disease including IL-5 and IL13 mapping within the "IL-4 gene cluster" in chromosome $5 \mathrm{q} 31.1$, or within 5q31.2-q33. Marsh et al looked for linkage between total serum $\operatorname{IgE}$ and multi-allergen $\operatorname{IgE}$ antibody and several polymorphic genetic markers in and around chromosome $5 \mathrm{q} 31.1-\mathrm{q} 33$, with a primary focus on markers mapping within the IL-4 gene itself and in or close to the IL-4 cluster (fig 2). The analysis centred on 170 subjects from 11 large Caucasian Amish families who were selected on the basis of detectable serum IgE to common inhalant allergens in at least one child. ${ }^{61}$ Using the sibling pair method of analysing the data, Marsh found significant evidence for linkage for IL4-R1, interferon releasing factor 1 (IRF-1), IL-9, D5S393, and D5S399 located in 5q31.1 with the total serum level of IgE. The $p$ value for IL4-R1 was 0.0069 , and with adjustment for multiallergen IgE antibody this improved slightly to 0.0023 . However, somewhat strangely, none of the markers showed evidence for linkage with specific or cognate IgE antibody responses. Subsequent exclusion of all siblings who had detectable
IgE antibody by the multiallergen test and analysis of only "non-atopic" individuals strengthened the evidence for linkage with total IgE, the $\mathrm{p}$ value for IL4-R1 improving further to $0 \cdot 000004$.

Marsh employed complex segregation analysis to analyse the distribution of total IgE among the 170 Amish family members and found significant evidence for the genetic determination of total IgE with a dominant high IgE model being slightly favoured over the dominant low model. When both of these models were used in lod score analyses, the data were consistent with linkage to the 5q31.1 markers in each case, with the maximum lod scores being in the range of $1 \cdot 5-2 \cdot 0$. These workers interpret their findings as demonstrating a likely role for IL- 4 or neighbouring gene in determining non-cognate IgE production.

Further evidence for the potential importance of the cytokine cluster on chromosome $5 \mathrm{q}$ has been provided by the study of Meyers et $a l^{62}$ Segregation analysis was performed on data from 92 families from Northern Holland ascertained through a parent with a diagnosis of asthma who were first studied approximately 25 years ago. Families were selected through a proband with symptomatic asthma who met the following criteria at the time of the first study: $<45$ years of age, bronchial hyperresponsiveness to histamine, and non-smoking. The original evaluation included skin tests to a variety of allergens, blood and sputum eosinophil counts, pulmonary function testing, and bronchial responsiveness to histamine. Total serum IgE levels were not measured during the initial evaluation. Current evaluation included a standardised respiratory questionnaire, pulmonary function testing, bronchial responsiveness to inhaled histamine, skin tests, specific IgE to house dust mite and grass mix, and total IgE. Genotyping was performed on 55 families and the following markers were tested for linkage: IL-9, D5S393, fibroblast growth factor acidic (FGF-A), D5S436, colony stimulating factor1R (CSF-1R), D5S410, D5S412, and D5S415. The first two of these were also used by Marsh and both were found to be significant. Linkage was looked for using the sibling pair method and the lod score method using the genetic model obtained from the segregation analysis of recessive inheritance of high $\mathrm{IgE}$ levels. Positive evidence for linkage of a gene for IgE production was found to IL-9 $(p=N S)$, D5S393 ( $p=0.01)$, D5S436 ( $p<0.0005)$, and CSF-1R $(\mathrm{p}<0.05)$. Lod scores for these markers ranged from 0.82 to $3 \cdot 61$.

The work by Marsh et al was carried out in the Amish population, a genetically isolated group, and the study by Meyers et al looked at a population selected for asthma but examined for atopy. With a trait as common as atopy affecting up to $40 \%$ of the population, it is important to perform linkage studies in a random population selected without reference to atopy. This was undertaken in a random sample of 131 families with three or more children from general practice registers in and around Southampton. The families comprised 685 individuals (262 parents and 423 offspring). The mean age of the parents was 41.5 years (range 31-58 years) and of the children 12.9 years (range $2-30$ years). Seventeen $(6 \cdot 5 \%)$ of the parents had selfreported asthma, while $83(19 \cdot 8 \%)$ of children had self or parent-reported asthma, consistent with the prevalence of asthma in southern England. One hundred and seven $(40 \cdot 8 \%)$ of the parents and $189(45 \cdot 7 \%)$ of the children had a skin prick test of mean weal diameter of $3 \mathrm{~mm}$ or more. Each family member completed a structured written questionnaire on atopic symptoms and disease. Participants underwent skin prick testing for 14 common allergens, and bronchial responsiveness to histamine was measured. Total IgE levels were also assessed. A number of markers around candidate loci, namely IL-4 receptor (D16S298), CD23 
(D19S177), interferon $\alpha$ (IFN $\alpha$ ), IL-11 (D19S112), tumour necrosis factor $\beta$ (TNF- $\beta$ ), IL- $2 \beta$ receptor, IFN $\gamma$, $\mathrm{Fc}_{\varepsilon} \mathrm{R} 1 \alpha$ (D1S104), and IL-9, were examined. The alleles were sized using an ABI 373A automated DNA sequencer.

In considering the phenotype to be analysed the approach we adopted to define atopy in the analysis of the data was the use of stepwise principal component regression of six traits (log IgE, skin prick test, bronchial hyperresponsiveness, history of wheezing, history of eczema, and history of seasonal rhinitis). ${ }^{51}$ Atopy was defined as the derived first principal component of the age and sexadjusted traits. This definition of atopy was dominated by serum $\operatorname{IgE}$, and so linkage and association analysis are based on age and sex-corrected log IgE. Linkage and association analysis on the sample of 131 random families demonstrated allelic association between the serum $\mathrm{IgE}$ level and IL-9 on chromosome $5 q(p<0 \cdot 005) .{ }^{63}$ Given the numbers of markers tested, significant association is to be expected in some cases by chance, and these findings may be due to a type 1 error. However, this is unlikely for two reasons. Firstly, the interleukin cluster around IL-9 contains many attractive candidate loci including IL-4. The markers used in this study were not randomly selected, and candidate loci in this region have biological plausibility. Secondly, linkage for serum total IgE levels has previously been shown in this region of chromosome 5 in the two studies mentioned above. ${ }^{6162}$ Further work is now underway on a sample of multiplex families in which two or more members have a diagnosis of asthma. Markers in and around the cytokine cluster on chromosome 5 will be examined including D5S436, D5S393, D5S658, IL-4, and IL-9. The $\mathrm{Fc}_{\varepsilon} \mathrm{R} 1$ marker on chromosome $11 \mathrm{q}$ will also be tested in addition to another random marker on chromosome 11q, D11527.

\section{Conclusion}

New techniques for scanning the human genome promise great advances in tracking the origins of disorders caused by multiple genes. However, it is clear from the studies presented in this overview that we are far from understanding the genetic basis of asthma and atopy and their interaction with the environment. It is also clear that agreement must be reached on definition of the phenotype and methods of ascertainment in order to carry out large multicentre collaborative studies. Positive findings need to be validated in different populations selected for the presence of the disease and then confirmed in a random population where the prevalence of asthma and atopy will also be expected to be significant.

\section{University Medicine,}

Centre Block,

Southampton General Hospital, Southampton SO9 $4 X Y$ $U K$

1 Ohe M, Munakata M, Hizawa N, Itoh A, Doi I, Yamaguchi E, et al. Beta adrenergic receptor gene restriction fragment length polymorphism and bronchial asthma. Thorax 1995;50:353-9.

2 Luisetti M, Pignatti PF. The search for susceptibility genes of COPD. Monaldi Arch Chest Dis 1995;50:28-32.

3 Davies JL, Kawaguchi Y, Bennett ST, Copeman JB, Cordell HJ, Pritchard LE, et al. A genome-wide search for human type 1 diabetes susceptibility genes. Nature 1994;371:130-6.

4 Pepys J. "Atopy": a study in definition. Allergy 1994;49:397-9.

5 Burrows B, Fernando D, Martinez MD, Halonen M, Barbee RA, Cline MG. Association of asthma with serum IgE levels and skin test reactivity to allergens. $N$ Engl $\mathcal{f}$ Med 1989;320:271-7.

6 Sears MR, Burrows B, Flannery EM, Herbison GP, Hewitt CJ, Holdaway MD. Relation between airway responsiveness and serum IgE in children with asthma and in apparently normal children. N Engl f Med 1991;325 1067-71.

7 Sears MR, Burrows B, Herbison GP, Holdaway MD, Flannery EM. Atopy in childhood. II. Relationship to airway responsiveness, hay fever and asthma. Clin Exp Allergy 1993;23:949-56.
8 Deal EC, McFadden ER, Ingram RH, Breslin FJ, Jaeger JJ. Airway responsiveness to cold air and hyperpnea in normal subjects and in those with hay fever and asthma. Am Rev Respir Dis 1980;121:621-8.

9 Juniper EF, Frith PA, Hargreave FE. Airway responsiveness to histamine and methacholine: relationship to minimum treatment to control symptoms of methacholine: relationship to minir

10 Josephs LK, Gregg I, Mullee MA, Holgate ST. Nonspecific bronchial reactivity and its relationship to the clinical expression of asthma. A longitudinal study. Am Rev Respir Dis 1989;140:350-7.

11 Boulet L-P, Cartier A, Thomson NC, Roberts RS, Dolovich J, Hargreave FE. Asthma and increases in nonallergic bronchial responsiveness from seasonal pollen exposure. F Allergy Clin Immunol 1983;71:399-406.

12 Omenaas E, Bakke P, Elsayed S, Hanoa R, Gulsvik A. Total and specific serum IgE levels in adults: relationship to sex, age and environmental factors. Clin Exp Allergy 1994;24:530-9.

13 Villar T, Holgate ST. IgE, smoking and lung function. Clin Exp Allergy 1994;24:508-10.

14 Sears MR, Burrows B, Flannery EM, Herbison GP, Holdaway MD. Atopy in childhood. 1. Gender and allergen related risks for development of hayfever and asthma. Clin Exp Allergy 1993;23:941-8.

15 Weiss ST, Tager IB, Munoz A, Speizer FE. The relationship of respiratory infections in early childhood to the occurrence of increased levels of bronchial responsiveness and atopy. Am Rev Respir Dis 1985;131:573-8.

16 O'Connor GT, Weiss ST, Tager IB, Speizer FE. The effect of passive smoking on pulmonary function and nonspecific bronchial responsivenes in a population-based sample of children and young adults. Am Rev Respir Dis 1987;135:800-4

17 Bazaral M, Orgel A, Hamburger RN. Genetics of IgE and allergy: serum IgE levels in twins. F Allergy Clin Immunol 1974;54:288-304.

18 Wuthrich B, Baumann RA, Fries RA, Schnyder UW. Total and specific IgE (RAST) in atopic twins. Clin Allergy 1981;11:147-54.

19 Townley R, Bewtra A, Watt G, Burke BS, Carney BS, Nair N. Comparison of allergen skin-test responses in monozygous and dizygous twins. $\mathcal{F}$ Allergy Clin Immunol 1980;65:214.

20 Hanson B, McGue M, Roitman-Johnson B, Segal NL, Bouchard TJ Blumenthal MN. Atopic disease and immunoglobulin $\mathrm{E}$ in twins reared apart and together. Am $\mathcal{F}$ Hum Genet 1991;48:873-9.

21 Gerrard JW, Rao DC, Morton NE. A genetic study of immunoglobulin E. Am $\mathcal{F}$ Hum Genet 1978;30:46-58.

$22 \mathrm{Ott}$ J. Maximum likelihood estimation by counting methods under polygenic and mixed models in human pedigrees. Am $\mathcal{F}$ Hum Genet 1980;31:161-75.

23 Blumenthal MN, Namboodiri K, Mendell N, Gleich G, Elston RC, Yunis E. Genetic transmission of serum IgE levels. Am $\mathcal{F}$ Med Genet 1981;10: 219-28.

24 Hasstedt SI, Meyers DA, Marsh DM. Inheritance of immunoglobulin E: genetic model fitting. Am $\mathcal{F}$ Med Genet 1983;14:61-6.

25 Meyers DA, Beaty TH, Freidhoff LR, Marsh DG. Inheritance of total serum IgE (basal levels) in man. Am f Hum Genet 1987;41:51-62.

26 Cookson WOCM, Hopkin JM. Dominant inheritance of atopic immunoglobulin E responsiveness. Lancet 1988; i:86-8.

27 Dizier MH, Hill M, James A, et al. Genetic control of basal IgE after accounting for specific atopy. Genet Epidemiol 1993;10:333-4.

28 Cookson WOCM, Sharp PA, Faux JA, Hopkin JM. Linkage between immunoglobulin $\mathrm{E}$ responses underlying asthma and rhinitis and chromosome 11q. Lancet 1989;i:1292-4.

29 Young RP, Sharp PA, Lynch JR, Faux JA, Lathrop GM, Cookson WOCM et al. Confirmation of genetic linkage between atopic IgE responses and chromosome 11q13. F Med Genet 1992;29:236-8.

30 Hopkin JM, Cookson WOCM, Young RP. Asthma, atopy, and genetic linkage. Ann N Y Acad Sci 1991;629:26-30.

31 Moffatt MF, Sharp PA, Faux JA, Young RP, Cookson WOCM, Hopkin JM. Factors confounding genetic linkage between atopy and chromosome 11. Clin Exp Allergy 1992;22:1046-51.

32 Shirakawa T, Hashimoto T, Furuyama J, Morimoto K. Linkage between severe atopy and chromosome 11q13 in Japanese families. Clin Genet 1994;46:228-32.

33 Collee JM, ten Kate LP, de Vries HG, Kliphuis JW, Bouman K, Scheffer $\mathrm{H}$. Allele sharing on chromosome $11 \mathrm{q} 13$ in sibs with asthma and atopy. Lancet 1993;342:936.

34 Sandford AJ, Shirakawa T, Moffatt MF, et al. Localisation of atopy and $\beta$ subunit of high affinity IgE receptor $\left(\mathrm{Fc}_{\varepsilon} \mathrm{R} 1\right)$ on chromosome $11 \mathrm{q}$. Lance 1993;341:332-4

35 Sutton BJ, Gould H. The human IgE network. Nature 1993;366:421-8.

36 Ravetch JV, Kinet J-P. Fc receptors. Ann Rev Immunol 1991;9:457-92.

37 Scharenberg $\mathrm{AM}$, Kinet J-P. Initial events in $\mathrm{Fc}_{\varepsilon} \mathrm{R} 1$ signal transduction. $\mathcal{f}$ Allergy Clin Immunol 1994;94:1142-6.

38 Gordon JR, Burd PR, Galli SJ. Mast cells as a source of multifunctional cytokines. Immunol Today 1990;11:458-63.

39 Punnonen J, Aversa G, Cocks BG, McKenzie ANJ, Menon S, Zurawski $\mathrm{G}$, et al. Interleukin 13 induces interleukin 4-independent IgC4 and IgE synthesis and CD23 expression by human B cells. Proc Natl Acad S 1993;90:3730-4

40 Shirakawa T, Li A, Dubowitz M, Dekker JW, Shaw AE, Faux JA, et al. Association between atopy and variants of the $\beta$ subunit of the high affinity immunoglobulin E receptor. Nature Genetics 1994;7:125-30.

41 Cookson WOCM, Young RP, Sandford AJ, Moffatt MF, Shirakawa T, Sharp PA, et al. Maternal inheritance of atopic IgE responsiveness on chromosome 11q. Lancet 1992;340:381-4.

42 Godfrey KM, Barker DJP, Osmond C. Disproportionate fetal growth and raised IgE concentration in adult life. Clin Exp Allergy 1994;24:641-8.

43 Chandra RK. Interactions between early nutrition and the immune system In: Bock JL, ed. The childhood environment and adult disease. Ciba Symposium 156. Chichester: John Wiley, 1991:77-92.

44 Warner JA, Miles EA, Jones AC, Quint DJ, Colwell BM, Warner JO. Is deficiency of interferon gamma production by allergen triggered cord deficiency of interferon gamma production by allergen triggered cord

45 Tang MLK, Kemp AS, Thorburn J, Hill DJ. Reduced interferon- $\gamma$ secretion in neonates and subsequent atopy. Lancet 1994;344:983-5.

46 Amelung PJ, Panhuysen CIM, Postma DS, Levitt RC, Koeter GH, Francomano CA, et al. Atopy and bronchial hyperresponsiveness: exclusion of linkage to mark.

47 Hizawa N, Yamaguchi $\mathrm{E}$, Ohe $\mathrm{M}$, Itoh $\mathrm{A}$, Furuya $\mathrm{K}$, Ohnuma $\mathrm{N}$, et al. Lack of linkage between atopy and locus 11q13. Clin Exp Allergy 1992; 22:1065-9. 
48 Rich SS, Roitman-Johnson B, Greenberg B, Roberts S, Blumenthal MN Genetic analysis of atopy in three large kindreds: no evidence of linkage to D11S97. Clin Exp Allergy 1992;22:1070-6.

49 Lympany P, Welsh KI, Cochrane GM, Kemeny DM, Lee TH. Genetic analysis of the linkage between chromosome 11q and atopy. Clin Exp Allergy 1992:22:1085-92.

50 Coleman R, Trembath RC, Harper JI. Chromosome $11 \mathrm{q} 13$ and atopy and underlying atopic eczema. Lancet 1993;341:1121-2.

51 Lawrence S, Beasley R, Doull I, Begishvili B, Lampe F, Holgate ST, et al. Genetic analysis of atopy and asthma as quantitative traits and ordered polychotomies. Ann Hum Genet 1994;58:359-68.

52 Cattanach BM, Jones J. Genetic imprinting in the mouse: implications for gene regulation. F Inher Metab Dis 1994;17:403-20.

53 Young RP, Dekker JW, Wordsworth BP, Schou C, Pile KD, Matthiesen F, et al. HLA-DR and HLA-DP genotypes and immunoglobulin $E$ responses to common major allergens. Clin Exp Allergy 1994;24:431-9.

54 Howell WM, Holgate ST. HLA genetics and allergic disease. Thorax 1995; $50: 815-8$

55 Moffatt MF, Hill MR, Cornelis F, Schou C, Faux JA, Young RP, et al. Genetic linkage of T-cell receptor $\alpha / \delta$ complex to specific IgE responses.
Lancet $1994 ; 343: 1597-600$.

56 Marsh DG, Hsu SH, Roebber M, Ehrlich-Kautzky E, Friedhoff LR, Meyers DA, et al. HLA-Dw2: a genetic marker for human immune response to short ragweed pollen allergen Ra5. I Exp Med 1982;155:1439-51.
57 Mosmann TR, Coffman RL. Th1 and Th2 cells: different patterns of lymphokine secretion lead to different functional properties. Ann Rev Immunol 1989;7:145-73.

58 Ricci M, Rossi O, Bertoni M, Matucci A. The importance of Th2-like cells in the pathogenesis of airway allergic inflammation. Clin Exp Allergy 1993; 23:360-9.

59 Bradding P, Roberts JA, Britten KM, Montefort S, Djukanovic R, Mueller $\mathrm{R}$, et al. Interleukin- $4,-5$, and -6 and tumour necrosis factor- $x$ in normal and asthmatic airways: evidence for the human mast cell as a source of and asthmatic airways: evidence for the human mast cell as

60 Mueller R, Heusser CH, Rihs S, Brunner T, Bullock GR, Dahinden CA. Immunolocalization of intracellular interleukin-4 in normal human peripheral blood basophils. Eur 7 Immunol 1994;24:21 35-40.

61 Marsh DG, Neely JD, Breazeale DR, Ghosh B, Friedhoff LR, Ehrlich Kautzky E, et al. Linkage analysis of IL 4 and other chromosome $5 \mathrm{q} 31.1$ markers and total serum immunoglobulin E concentrations. Science 1994 264:1152-6.

62 Meyers DA, Postma DS, Panhuysen CIM, Xu J, Amelung PJ, Levitt RC, et al. Evidence for a locus regulating total serum IgE levels mapping to chromosome 5. Genomics 1994;23:464-70.

63 Doull IJM, Lawrence S, Watson M, Begishvili B, Beasley R, Lampe F, et al. Allelic association of markers on chromosomes $5 \mathrm{q}$ and $11 \mathrm{q}$ with atopy and bronchial hyperresponsiveness. Am Rev Respir Crit Care Med 1996 (in press). 